(c) American Dairy Science Association, 2004.

\title{
Short Communication: Growth Characteristics of Streptococcus uberis in UHT-Treated Milk
}

\author{
B. Dogan and K. J. Boor \\ Department of Food Science \\ Cornell University, Ithaca, New York 14853
}

\begin{abstract}
Streptococcus uberis is an important environmental pathogen associated with bovine mastitis as well as with high total bacterial numbers in bulk tank milk. This study was conducted to determine whether $S$. $u b$ eris reproduction is likely to contribute to high bacterial numbers in bulk tank milk. Four $S$. uberis raw milk isolates were individually inoculated into UHT-treated milk and incubated at 4.4 or $7^{\circ} \mathrm{C}$ for up to $5 \mathrm{~d}$ to simulate appropriate cooling; at $10^{\circ} \mathrm{C}$ for $5 \mathrm{~d}$ to simulate marginally inadequate cooling; at 21 or $25^{\circ} \mathrm{C}$ for $7 \mathrm{~h}$ to simulate ambient temperatures; or at $32^{\circ} \mathrm{C}$ for $7 \mathrm{~h}$ to simulate elevated temperature conditions. None of the $S$. uberis isolates grew at either 4.4 or $7^{\circ} \mathrm{C}$. Streptococcus $u b$ eris growth at $10^{\circ} \mathrm{C}$ appeared to be ribotype-specific. Although ribotype 116-520-S-1 isolates did not grow at $10^{\circ} \mathrm{C}$, ribotype $116-520-\mathrm{S}-2$ isolate numbers increased up to $3.5 \log _{10} \mathrm{cfu} / \mathrm{mL}$ within $5 \mathrm{~d}$. Generation times were calculated as $2.7 \pm 0.1 \mathrm{~h}, 2.1 \pm 0.1 \mathrm{~h}$, and $1.0 \pm 0.1 \mathrm{~h}$ for 116-520-S-1 isolates and $1.8 \pm 0.4 \mathrm{~h}, 1.3 \pm 0.3 \mathrm{~h}$, and $0.8 \pm 0.1 \mathrm{~h}$ for $116-520-\mathrm{S}-2$ isolates at 21,25 , and $32^{\circ} \mathrm{C}$, respectively. Our results suggest that high numbers of $S$. uberis in bulk tank milk are more likely to reflect high numbers of $S$. uberis shed by mastitic cows, rather than multiplication of these organisms under cooling conditions required for production of Grade A milk.
\end{abstract}

(Key words: Streptococcus uberis, growth, bulk tank milk, total bacterial counts)

Abbreviation key: BHI = brain heart infusion, $\mathbf{P M O}=$ Pasteurized Milk Ordinance, $\mathbf{T B C}=$ total bacte rial counts.

Streptococcus uberis is an important environmental pathogen associated with bovine mastitis (Hogan and Smith, 1997; Leigh, 1999). Cows with clinical mastitis caused by this organism have been shown to shed up to $10^{7} \mathrm{cfu} / \mathrm{mL}$ of $S$. uberis in their milk (Leigh, 1999). This organism is also commonly isolated from bovine

Received August 30, 2003.

Accepted October 27, 2003.

Corresponding author: K. Boor; e-mail: kjb4@cornell.edu. body sites, including the skin surface, genital tract, and tonsils, as well as from manure, soil, and bedding (Cullen and Little, 1969; Sharma and Packer, 1970; Razavi-Rohani and Bramley, 1981; Bramley, 1982). Streptococcus uberis has been demonstrated to contribute to elevated bacterial counts in farm bulk tank milk (Auldist and Hubble, 1998; Hayes et al., 2001). To illustrate, $S$. uberis was identified as the predominant organism in over $50 \%$ of brief, sporadic increases (socalled "spikes") in bulk tank milk total bacteria counts observed during daily monitoring of bulk tank microflora on multiple farms (Hayes et al., 2001).

Total bacterial count (TBC) of bulk milk is an important measure of milk quality and can assist in evaluating mastitis outbreaks, farm sanitation efficacy and proper milk handling practices (Farnsworth, 1993). According to Pasteurized Milk Ordinance (PMO) standards, TBC of Grade A milk for an individual producer should not exceed 100,000 cfu/mL (FDA, 2001). Elevated numbers of bacteria in milk generally arise from at least one of 4 common sources: dirty teats, soiled equipment, mastitis infections, and poor refrigeration (Blowey et al., 1999; Murphy and Boor, 2000).

Growth characteristics for several bacteria in milk have been reported previously (Lawton and Nelson, 1954; Andrey and Frazier, 1959; Fang et al., 1993). No similar studies have been reported for $S$. uberis. A better understanding of the growth characteristics of $S$. uberis will provide insight into the causes of TBC increases associated with this organism. The objective of this study was to determine experimental time/temperature conditions that allow $S$. uberis growth.

The $S$. uberis isolates shown in Table 1 were selected from a strain collection previously described by Hayes et al. (2001). Briefly, isolates were obtained by spreadplating bulk tank milk samples $(0.1 \mathrm{~mL})$ on modified Edwards medium (Oxoid, Hampshire, England). Plates were incubated at $32^{\circ} \mathrm{C}$. Selected isolates were identified with the API 20 Strep test according to the manufacturer's instructions (BioMerieux Vitek, Hazelwood, MO). All S. uberis isolates in the strain collection grouped into one of 2 EcoRI ribotypes: 116-520-S-1 or 116-520-S-2 (http://www.pathogentracker.net, accessed August 30, 2003). Ribotyping, based on scoring 
Table 1. Growth of Streptococcus uberis at $4,7,10,21,25$, and $32^{\circ} \mathrm{C}$ in UHT milk.

\begin{tabular}{llllllll}
\hline & \multicolumn{7}{c}{ Growth at } \\
\cline { 2 - 7 } Isolate & Ribotype & $4^{\circ} \mathrm{C}$ & $7^{\circ} \mathrm{C}$ & $10^{\circ} \mathrm{C}$ & $21^{\circ} \mathrm{C}$ & $25^{\circ} \mathrm{C}$ & $32^{\circ} \mathrm{C}$ \\
\hline FSL A3-068 & $116-520-S-1$ & - & - & - & + & + & + \\
FSL A3-092 & $116-520-S-1$ & - & - & - & + & + & + \\
FSL A3-079 & $116-520-S-2$ & - & - & + & + & + & + \\
FSL C1-308 & $116-520-S-2$ & - & - & + & + & + & + \\
\hline
\end{tabular}

rRNA gene restriction fragment polymorphisms, can type bacterial isolates to the genus, species and strain levels (Bruce et al., 1995; Bruce, 1996). To represent different genetic groups among $S$. uberis isolates, we selected 2 isolates from each EcoRI ribotype for this study. Isolates were grown overnight in $5 \mathrm{~mL}$ of commercial UHT-treated milk incubated at $37^{\circ} \mathrm{C}$. Overnight cultures were diluted serially in PBS, and $0.1 \mathrm{~mL}$ of the appropriate dilutions were inoculated into $5 \mathrm{~mL}$ of UHT milk to give approximately $10^{3}$ to $10^{4} \mathrm{cfu} / \mathrm{mL}$ of $S$. uberis in each of 6 pairs of tubes. For each isolate, one pair of tubes was incubated for $5 \mathrm{~d}$ at each $4.4^{\circ} \mathrm{C}$ or at $7^{\circ} \mathrm{C}$ to represent appropriate refrigeration conditions as described in the PMO (FDA, 2001). A third pair of tubes was incubated at $10^{\circ} \mathrm{C}$ for $5 \mathrm{~d}$ to simulate marginally inadequate cooling. Fourth and fifth pairs were incubated at 21 or $25^{\circ} \mathrm{C}$ for $7 \mathrm{~h}$ to simulate ambient temperatures. The last pair was incubated at $32^{\circ} \mathrm{C}$ for $7 \mathrm{~h}$ to simulate elevated temperatures. Daily, 0.1-mL volumes of the cultures from the samples incubated at $4.4,7$, or $10^{\circ} \mathrm{C}$ were serially diluted in PBS and surface plated in duplicate $(0.1 \mathrm{~mL})$ onto brain heart infusion (BHI; Becton Dickinson, Sparks, MD) agar. Samples incubated at 21,25 , or $32^{\circ} \mathrm{C}$ were plated in duplicate onto $\mathrm{BHI}$ at 0 and $7 \mathrm{~h}$ postinoculation. Brain heart infusion plates were incubated at $37^{\circ} \mathrm{C}$ for $24 \mathrm{~h}$ prior to enumeration of bacterial colonies. All experiments were repeated twice. Generation times were calculated by the following formula:

$$
\mathrm{g}=(\mathrm{T} \log 2) /(\log b-\log a),
$$

where $\mathrm{g}$ is generation time, $\mathrm{T}$ is the time interval for the growth experiment, $a$ is the initial bacterial number, and $b$ is the bacterial number at the end of the incubation period (e.g., $7 \mathrm{~h}$ at 21,25 , or $32^{\circ} \mathrm{C}$ ).

Table 1 summarizes the abilities of the $S$. uberis isolates to grow in UHT milk at different temperatures. None of the 4 isolates grew at $4.4^{\circ} \mathrm{C}$ or $7^{\circ} \mathrm{C}$. Ribotype 116-520-S-2 isolate numbers increased by either 1.5 or $3.5 \log _{10} \mathrm{cfu} / \mathrm{mL}$ following $5 \mathrm{~d}$ at $10^{\circ} \mathrm{C}$ (Figure 1 ). Ribotype 116-520-S-1 isolates did not grow at $10^{\circ} \mathrm{C}$. Generation times at 21,25 , and $32^{\circ} \mathrm{C}$ were determined for all isolates. Ribotype 116-520-S-2 isolate generation times were shorter than those for ribotype 116-520-S-1 isolates. Generation times were $2.7 \pm 0.1 \mathrm{~h}, 2.10 .1 \pm \mathrm{h}, 1$ $\pm 0.1 \mathrm{~h}$ for $116-520-\mathrm{S}-1$ isolates and $1.8 \pm 0.4 \mathrm{~h}, 1.3 \pm$ $0.3 \mathrm{~h}$, and $0.8 \pm 0.1 \mathrm{~h}$ for $116-520-\mathrm{S}-2$ isolates at 21,25 , and $32^{\circ} \mathrm{C}$, respectively.

Temperature and duration of milk storage on the farm affect microbial numbers in raw milk (Cousins and Bramley, 1981). According to PMO standards, raw milk for pasteurization must be cooled to $10^{\circ} \mathrm{C}$ or less within $4 \mathrm{~h}$ or less after initiation of the first milking, and to $7^{\circ} \mathrm{C}$ or less within $2 \mathrm{~h}$ after the completion of milking. Blend temperatures of multiple milkings should not exceed $10^{\circ} \mathrm{C}$ (FDA, 2001). Although $S$. uberis can reproduce in $<3 \mathrm{~h}$ at temperatures $\geq 21^{\circ} \mathrm{C}$, we have shown that this organism should not reproduce during storage if PMO standards for bulk tank milk temperature control are followed. If milk were to be produced and stored at the high temperatures used in this study (e.g., 21,25 , or $32^{\circ}$ C), S. uberis would not necessarily

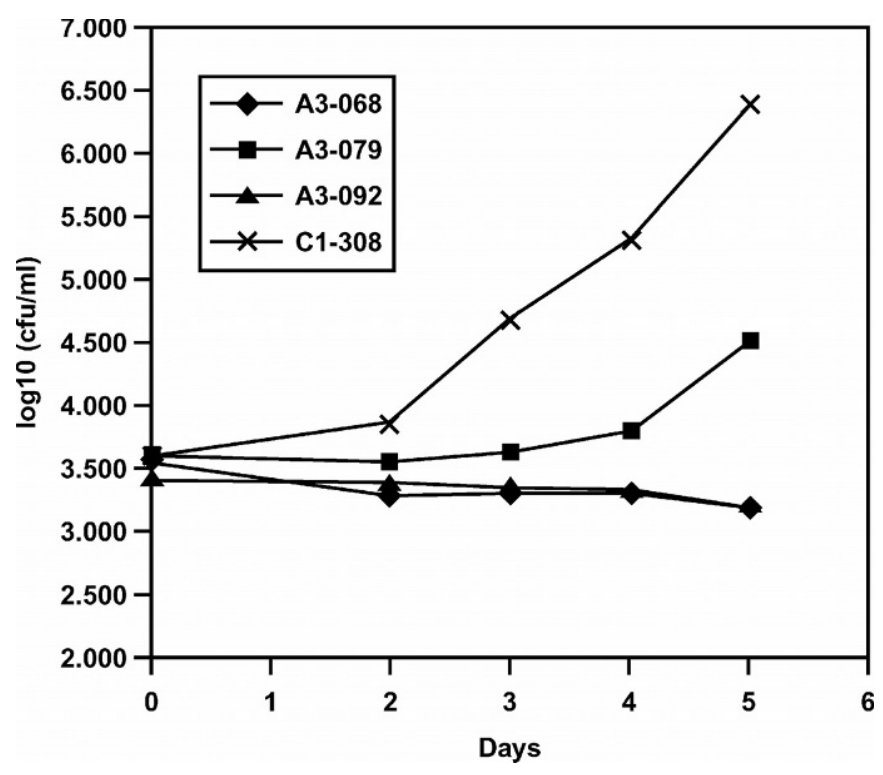

Figure 1. Growth of Streptococcus uberis at $10^{\circ} \mathrm{C}$ in UHT milk. Mean $\log _{10}$ values (cfu/mL) obtained from duplicate tubes in one experiment are shown. Although absolute bacterial numbers at each time point differed between experiments, in both trials, postinoculation bacterial growth initiated at the same times, yielding similar relative increases in bacterial numbers. 
predominate the total microflora, especially if it had been initially present at low numbers in the raw milk, as many different types of organisms also would be capable of reproducing under these conditions. This work has demonstrated that $S$. uberis does not grow at refrigeration temperatures required by the PMO (FDA, 2001). These findings suggest that high levels of $S$. uberis in properly cooled bulk tank milk are indicators of mastitis infection and are unlikely to reflect $S$. uberis growth in the bulk tank.

\section{REFERENCES}

Andrey, J., and W. C. Frazier. 1959. Psychrophiles in milk held 2 days in farm bulk cooling tanks. J. Dairy Sci. 42:1781-1784.

Auldist, M. J., and I. B. Hubble. 1998. Effects of mastitis on raw milk and dairy products. Aust. J. Dairy Technol. 53:28-36.

Blowey, R., P. Edmondson, and J. Davis. 1999. Bacterial counts in bulk milk-an update. In Practice 21:531-533.

Bramley, A. J. 1982. Sources of Streptococcus uberis in the dairy herd. I. Isolation from bovine faeces and from straw bedding of cattle. J. Dairy Res. 49:369-373.

Bruce, J. L., R. J. Hubner, E. M. Cole, C. I. McDowell, and J. A. Webster. 1995. Sets of EcoRI fragments containing ribosomal RNA sequences are conserved among different strains of Listeria monocytogenes. Proc. Natl. Acad. USA 92:5229-5233.

Bruce, J. 1996. Automated system rapidly identifies and characterizes microorganisms in food. Food Technol. 50:77-81.

Cousins, C. M., and A. J. Bramley. 1981. The microbiology of raw milk. Pages 119-163 in Dairy Microbiology. Vol. 1. R. K. Robinson, ed. Applied Science Publishers, Englewood, NJ.
Cullen, G. A., and T. W. Little. 1969. Isolation of Streptococcus uberis from the rumen of cows and from soil. Vet. Rec. 85:115-118.

Fang, W., M. Shi, L. Huang, Q. Shao, and J. Chen. 1993. Growth of lactobacilli, Staphylococcus aureus and Escherichia coli in normal and mastitic milk and whey. Vet. Microbiol. 37:115-125.

Farnsworth R. J. 1993. Microbiologic examination of bulk tank milk. Vet. Clin. North. Am. Food Anim. Pract. 9:469-474.

FDA. 2001. Grade "A" Pasteurized Milk Ordinance. U.S. Dept. of Health and Human Services, Public Health Service. Publication No. 229. Washington, DC.

Hayes, M. C., R. D. Ralyea, S. C. Murphy, N. R. Carey, J. M. Scarlett, and K. J. Boor. 2001. Identification and characterization of elevated microbial counts in bulk tank raw milk. J. Dairy Sci. 84:292-298.

Hogan, J. S., and K. L. Smith. 1997. Occurrence of clinical and subclinical environmental streptococcal mastitis. Pages 59-75 in Proceedings of the Symposium on Udder Health Management for Environmental Streptoccoci 1997. National Mastitis Council Inc., Madison, WI.

Lawton, W. C., and F. E. Nelson. 1954. The effect of storage temperatures on the growth of psychrophilic organisms in sterile and laboratory pasteurized skim milks. J. Dairy Sci. 37:1164-1172.

Leigh, J. A. 1999. Streptococcus uberis: A permanent barrier to the control of bovine mastitis? Vet. J. 157:225-238.

Murphy, S. C., and K. J. Boor. 2000. Trouble-shooting sources and causes of high bacteria counts in raw milk. Dairy Food Environ. Sanit. 20:606-611.

Razavi-Rohani, M., and A. J. Bramley. 1981. A study of the frequency and distribution of Streptococcus uberis contamination on the body of lactating and non-lactating cows. Indian Vet. J. 58:804-811.

Sharma, R. M., and R. A. Packer. 1970. Occurrence and ecologic features of Streptococcus uberis in the dairy cow. Am. J. Vet. Res. 31:1197-1202. 